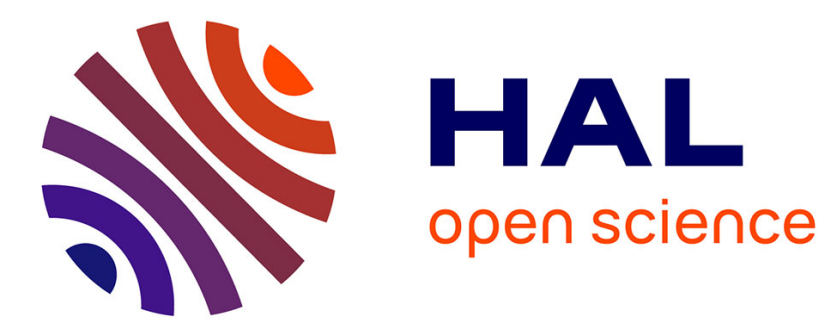

\title{
Capital Stock Depreciation, Tax Rules, and Composition of Aggregate Investment
}

\author{
Daniel Levy
}

\section{To cite this version:}

Daniel Levy. Capital Stock Depreciation, Tax Rules, and Composition of Aggregate Investment. Journal of Economic and Social Measurement, 1995, 21 (1), pp.45-65. 10.3233/JEM-1995-21104 . hal-02382794

\section{HAL Id: hal-02382794 \\ https://hal.science/hal-02382794}

Submitted on 27 Nov 2019

HAL is a multi-disciplinary open access archive for the deposit and dissemination of scientific research documents, whether they are published or not. The documents may come from teaching and research institutions in France or abroad, or from public or private research centers.
L'archive ouverte pluridisciplinaire HAL, est destinée au dépôt et à la diffusion de documents scientifiques de niveau recherche, publiés ou non, émanant des établissements d'enseignement et de recherche français ou étrangers, des laboratoires publics ou privés. 


\title{
Capital Stock Depreciation, Tax Rules, and Composition of Aggregate Investment*
}

by

\author{
Daniel Levy \\ Department of Economics \\ Emory University \\ Atlanta, GA 30322-2240 \\ Ph: (404) 727-2941 \\ Fax: (404) 727-4639 \\ econdl@unix.cc.emory.edu
}

Last Revision: November 23, 1994

JEL Codes: E22, C82

Key Words: Time Varying Depreciation Rate, Capital Stock, Consumer Durable Goods, Producer Durable Goods, Business Structures, Technological Progress

\footnotetext{
* I am grateful to John Musgrave of the Bureau of Economic Analysis and Stephen Oliner of the Board of Governors for kindly answering my questions and for providing some of the data used in this study. Martin J. Bailey, Bob Carpenter, John Musgrave, and Keith Shriver have read an earlier version of this manuscript and provided useful comments. I also thank Samiran Banerjee, Hashem Dezhbakhsh, and Varda Yaari for helpful discussions. Yihong Xia provided research assistance. The usual disclaimer applies. Address all correspondence to: Daniel Levy, Department of Economics, Emory University, Atlanta, GA 30322, U.S.A.
} 


\begin{abstract}
I estimate time varying aggregate capital stock depreciation rates for the post-war U.S. economy using capital-investment evolution equation along with the data on the annual net capital stock and corresponding quarterly gross investment series. I estimate depreciation rates of consumer durable goods, producer durable goods, and nonresidential business structures. The estimation results suggest that the three depreciation rate series have been behaving very differently over time. In particular, I find that over time the implied depreciation rate of nonresidential business structures has remained stable, the implied depreciation rate of consumer durable goods has been steadily declining, while the implied depreciation rate of producer durable goods has been increasing, especially during the last 10-15 years. These findings are interpreted in terms of the changes in the composition of the aggregate nonresidential business fixed and producer durable good capital stocks. In addition, I discuss the implications of the changes introduced during the 1980s in rules and regulations governing a depreciation accounting for tax purposes, and their effect on the estimates of capital depreciation rates derived in this paper. The main argument the paper makes is that technological progress may be leading to accelerated depreciation of producer durable goods and equipment since newer and more advanced technology makes older equipment obsolete. The empirical evidence reported in this paper supports this argument.
\end{abstract}




\section{Introduction}

Since physical capital depreciates during the process of production, a part of new investment is always used to replace the worn out capital. However, it is difficult to estimate the amount of new investment needed to replace the worn out capital in aggregate. This is because the process of capital depreciation is not directly observable or measurable. Therefore, it must be approximated based on some arbitrary assumptions on the life-length of various physical assets and on the way the services they provide are spread over this life. Having an accurate measure of depreciation is important since for a given gross investment, the size of net investment depends on depreciation. In addition, since replacement investment and capital depreciation tend to move together [Eisner (1972)], understanding capital depreciation may shed some light on the process of replacement investment. This is important since replacement investment accounts for about half of the gross investment. In addition, gross investment itself is important factor affecting the aggregate demand and therefore stabilization [Feldstein and Foot (1971)].

The standard theoretical as well as empirical macroeconomic literature usually treats the aggregate depreciation rate of capital as an exogenous constant. However, as Eisner (1972), Feldstein and Foot (1971), and Feldstein and Rothschild (1974) suggest, most of the actual fixed capital replacement made in practice is based on dynamically optimizing economic choice. This is because, "Plant and equipment neither evaporate by radioactive decay nor fall apart like the legendary 'one hoss shay'; rather they are scrapped and replaced when the balance of economic forces makes that decision most profitable" [Feldstein and Foot (1971), p. 50]. ${ }^{1}$ In addition, service lives of various capital stock depend on business conditions and production technology which obviously change over time. ${ }^{2}$ These considerations suggest that the depreciation rate will in general be endogenous and potentially time varying. ${ }^{3}$

In this paper I estimate annual aggregate capital stock depreciation rates for the post-war U.S. economy for all three main categories of the aggregate capital stock: consumer durable goods, producers durable goods and equipment, and business structures. ${ }^{4}$ I estimate these depreciation rates using the standard dynamic capital-investment evolution equation along with data on the annual net capital stock and corresponding quarterly gross investment series. I adopt this method since it is based on a well-accepted accounting relationship between investment and capital stock, and also because it allows the depreciation rate to vary with time. An additional advantage of the 
method is its simplicity.

The annual aggregate capital stock series used in this paper were recently revised by the Bureau of Economic Analysis following a recent comprehensive revision of the National Income and Product Accounts. These revisions include (1) the introduction of a new procedure for estimating construction series, (2) the change in the base period from 1982 to 1987, and (3) the inclusion of interest payments made by utility companies on own-account construction projects. In addition, the revised capital stock series are based on new service lives of various physical assets. As Musgrave (1992, p. 106) suggests, the resulting changes in the annual capital stock series are quite significant, especially after 1970.

The estimation results suggest that the three depreciation rate series have been behaving very differently over time. In particular, I find that over time the implied depreciation rate of nonresidential business structures has remained stable, the implied depreciation rate of consumer durable goods has been steadily declining, while the implied depreciation rate of producer durable goods has been increasing, especially during the last 10-15 years. These findings are interpreted in terms of the changes in the composition of the aggregate nonresidential business fixed and producer durable good capital stocks.

The main argument I make is that the technological advances made recently in the fields of computers and computerized equipment make these products obsolete in relatively short time, resulting in accelerated depreciation. In addition, the composition of the aggregate investment has been changing in such a way that the share of information processing and related equipment, which has relatively short service life, has been increasing. At the same time, the share of industrial equipment, industrial machinery, and transportation equipment, which have longer service life, has been decreasing. These two developments can explain the increasing depreciation rate of producer durable goods I find in this paper.

In addition, I discuss the implications of the changes introduced during the 1980s in rules and regulations governing the depreciation accounting for tax purposes, and their effect on the estimates of capital depreciation rates derived in this paper. In particular, I argue that the Reagan administration's 1981 Accelerated Cost Recovery System and the 1986 Modified Accelerated Cost Recovery System acts had a significant impact on the effective depreciation rates of producer durable goods. Recall that these acts were introduced to encourage capital investment by increasing the rate at which most fixed assets could be depreciated. This increased the present 
value of tax shield from depreciation, leading to accelerated depreciation, as predicted by Feldstein and Rothschild' (1974) theoretical analysis.

The paper is organized as follows. In the next section I describe the methodology and the data set used in the paper. In section 3, I report the estimated time varying capital stock depreciation rates. In section 4 , I interpret the estimation results by discussing the implications of technological innovations and various tax laws introduced during the 80 s for the implied rates of depreciation of various types of fixed capital. In addition, the findings are interpreted in light of the changes in the composition of the aggregate investment that took place during the last two decades. The paper ends with a brief summary of the findings and some concluding remarks.

\section{The Methodology and the Data}

The Bureau of Economic Analysis defines depreciation as the value of past investment lost through physical deterioration, obsolescence, accidents, and aging (Bureau of Economic Analysis, 1993). ${ }^{5}$ There are two main methods for estimating capital stock depreciation rates. One method is based on prices of used assets. Since the value of an asset depends on its future expected earnings, under rational expectations the value of partially worn-out capital is given by the present value of its initial cost minus the present value of its return up to this point. This corresponds to the expectations that induced the investors in the past to make this investment. Since the initial cost is incurred at the beginning when the actual investment takes place, but the returns are realized over time, the implicit interest on cost exceeds the implicit interest on return. Over its life, however, the accumulated interest on its return catches up upon the accumulated interest on its cost, so that at the end of asset's life it is fully paid off and its price is zero (plus its scrap value) [Wicksell (1934) and Robinson (1953)]. The method of estimating depreciation rates by examining the market prices of various vintages of used capital goods is essentially based on this idea. See Hulten and Wykoff (1981a, 1981b) for a survey of recent results.

The second method of estimating a capital stock depreciation rate tries to exploit the relationship between replacement investment and existing capital stock to measure the implied depreciation rate. See for example Feldstein and Foot (1971) or Eisner (1972). The difficulty with this approach is the fact that replacement investment is not directly observed and therefore is difficult to measure. Therefore, studies that use this approach rely primarily on replacement 
investment series constructed using various business survey results, which might not be reliable.

In this paper I estimate the annual time varying depreciation rate of capital stock using the standard dynamic capital-investment evolution equation. Let $K_{i}$ : denote a quarterly net capital stock for year:quarter $i: j$ and let $K_{i}$ denote the end of year $i$ net capital stock. Also denote investment of year:quarter $i: j$ by $I_{i \text { : }}$, and the quarterly depreciation rate of year $i$ by $\delta_{i}$, which by assumption remains unchanged within the period of a year. Then,

$$
\begin{aligned}
& K_{i: 1}=\left(1-\delta_{i}\right) K_{i-1}+I_{i: 1}, \\
& K_{i: 2}=\left(1-\delta_{i}\right) K_{i: 1}+I_{i: 2}, \\
& K_{i: 3}=\left(1-\delta_{i}\right) K_{i: 2}+I_{i: 3}, \text { and } \\
& K_{i: 4}=\left(1-\delta_{i}\right) K_{i: 3}+I_{i: 4},
\end{aligned}
$$

where $i=1947,48, \ldots, 90$. A recursive substitution of (1), (2), and (3) into (4), and using the fact that $K_{i: 4}=K_{i}$, yields

$$
K_{i}=\left(1-\delta_{i}\right)^{4} K_{i-1}+\left(1-\delta_{i}\right)^{3} I_{i: 1}+\left(1-\delta_{i}\right)^{2} I_{i: 2}+\left(1-\delta_{i}\right) I_{i: 3}+I_{i: 4}{ }^{1}
$$

Equation (5) expresses the quarterly depreciation rate of year $i, \delta_{i}$, as a nonlinear function of the last year's and this year's annual capital stock and this year's quarterly investment. The set of equations in (5) is solved for $\delta_{i}$ using Newton's iteration formula

$$
x_{n+1}=x_{n}-\frac{\left(x_{n}\right)}{f\left(x_{n}\right)}
$$

which provides an iterative solution to a nonlinear function of the form $f(x)=0$, where $n$ is the number of iterations. For most years a convergence was achieved within 3-4 iterations, although for some years we needed as many as 6 iterations. ${ }^{6}$

The data series used in this work consists of the annual real net capital stock series of the consumer durable goods, producer durable goods, and nonresidential business structures along with their corresponding quarterly investment series covering the period 1947:1-1990:4. Detailed 
annual capital stock data are constructed by the Bureau of Economic Analysis and the source of the series I use is Musgrave (1992), Tables 8 and 20. ${ }^{7}$ The source of the investment data is Citicorp (1992), series GCD87, GIPD87, and GIS87. The shares of various components withing the stock of producer durable goods and equipment plotted on Figure 3 are from Bureau of Economic Analysis (1993). All the original capital stock series used in this paper are computed using constant-cost valuation. All figures are in 1987 dollars.

\section{Estimation Results}

In Table 1, I present quarterly and annually compounded depreciation rates for consumer durable goods, producer durable goods and equipment, and business structure capital stock series computed using the above numerical iteration procedure. The compounded annual depreciation rates are also displayed on Figure 1. Average depreciation rates for various subperiods are summarized in Table 2. As the results indicate, the three depreciation rate series have been behaving very differently over time.

According to Figure 1, there has been no significant change in the depreciation rate of nonresidential business structures since mid-1950s. Although the depreciation rate seems to have increased slightly during the last two decades, quantitatively this increase is not significant. According to Table 1, the depreciation rate has fluctuated around 5 percent.

The stability of the depreciation rate of nonresidential business structures can be seen in Table 2 also where we have computed the average annual depreciation rate for the entire period as well as for the following four subperiods: 1948-72 and 1973-91, i.e., the periods before and after the 1973 oil price shock, and 1981-91 and 1986-91 subperiods. The last two subperiods are chosen to examine the effect of the Accelerated Cost Recovery System Tax Act of 1981 and the Modified Accelerated Cost Recovery System Tax Act of $1986 .{ }^{8}$ As these figures suggest, the average annual depreciation rate of nonresidential business structures has increased from 5.11 percent during the 1948-72 period to 5.24 percent during the 1973-91 period. Similar findings in terms of depreciation rates' stability is reported also by Hulten and Wykoff (1981a) who estimate annual depreciation rates of a sample of office buildings by using used physical asset prices and report reasonable stability of their estimates. ${ }^{9}$

According to Figure 1, the depreciation rate of consumer durable goods has been declining almost monotonically since early 1960s. The expenditure on most of the consumer durable goods 
is not tax deductible, and therefore it is likely that the estimated depreciation figures reported here reflect the pattern of the "true" depreciation implied by replacement investment in consumer durable goods. If this conjecture is correct, then the downward movement in the annual depreciation rate suggests that the actual average life (i.e., durability) of the consumer durable goods has increased, perhaps reflecting improvement in the quality of consumer durable goods. According to Table 2, the average annual depreciation rate of consumer durable goods has declined by more than three percentage points from 25.48 percent during the 1948-72 period to 22.11 percent during the 1973-91 period. According to the table, the average depreciation rate has declined further to about 21.5 percent during the last decade. This is a significant decrease.

The time series of producer durable goods depreciation rate also displays sharp changes during the last two decades. But in contrast with the depreciation rate of consumer durable goods, here we find that the annual depreciation rate, with the exception of a slight decline during the decade of 1960s, has been almost steadily increasing, especially since mid-1970s. As the figure indicates, the annual depreciation rate of producer durable goods has changed very little during the 1948-1972 period.

Not surprisingly, the first noticeable increase in the annual depreciation rate of producer durable goods occurs in 1974, immediately after the first oil price shock. The second change in the slope of the producer durable goods depreciation rate occurs around 1980-81, which coincides with the second oil price shock as well as the Reagan administration's Accelerated Cost Recovery System Tax Act of 1981. According to Table 2, the average annual depreciation rate of producer durable goods has increased by more than one and a half percentage points from 12.19 percent during the 1948-72 period to 13.72 percent during the 1973-91 period. According to the table, the average depreciation rate has increased further to over 15 percent during the 1986-91 period. This acceleration in the depreciation rate of producers durable goods and equipment coincides with the Modified Accelerated Cost Recovery System Tax Act which was enacted during Reagan administration in 1986.

At first look, the findings reported by Shriver (1986) seem to contradict the above results. However, a closer comparison of his findings with mine indicates that the two sets of the results do not really contradict each other. Shriver (1986) examines the stability assumption underlying the existing econometric derivations of empirical estimates of economic depreciation for industrial 
machinery and equipment. For this he uses pricing data compiled by experts of used asset dealers and appraisers for the years 1973, 1976, and 1980. Using the methodology of Hulten and Wykoff (1981a), Shriver (1986) finds that economic depreciation rates of producer durable goods are reasonably stable over time. My numerical estimates of the depreciation rates of producer durable goods for the years 1973, 1976, and 1980 are 12.25, 12.59, and 12.81 percent, respectively (See Table 1). Thus, my results also show that during these years the depreciation rate of producer durable goods remained stable. However, this conclusion can not be generalized to the entire postwar period. As discussed above and as the figures in Table 1 indicate, the depreciation rate of producer durable goods has been actually increasing, especially during the last 10-15 years. ${ }^{10}$

Gordon and Veitch (1986) also estimate aggregate capital stock depreciation rates using the iterative procedure used here. However, the findings they report are not identical to mine. According to their estimates, which cover the period 1919-1983, the average depreciation rate of consumer durable goods, producer durable goods, and nonresidential business structures for the 1947-83 period are $0.20,0.14$, and 0.06 , respectively. ${ }^{11}$ Thus, comparing these figures to my findings summarized in Table 2, it is clear that Gordon and Veitch's (1986) estimated depreciation rate of consumer durable goods is significantly lower than mine. On the other hand, their estimated depreciation rate of producer durable goods and business structure is slightly higher than mine. The main reason for these differences is the difference in the data set used. I use recently revised capital stock series which significantly differ from the older series Gordon and Veitch (1986) use. The revision of the capital stock series was done in conjunction with the recent comprehensive revision of the National Income and Product Accounts (NIPA). In addition to the inclusion of these NIPA revisions, the revised capital stock data as well as the revised NIPA estimates of consumption of fixed capital, reflect a revision in the service lives of several types of assets. It turns out that the resulting changes in the annual capital stock series are quite significant, especially after $1970 .{ }^{12}$

\section{Interpretation of the Findings}

In this section I try to interpret the findings reported in section 3 by considering the factors that could lead to the patterns of capital depreciation displayed in Figure 1. I consider two possible explanations. The first explanation is based on changes that took place in composition of the aggregate private nonresidential fixed capital as well as in composition of producer durable goods investment, especially during the last two decades. It is argued that the main driving force behind 
these changes is the technological progress of the last 15-20 years. The second explanation is based on economic factors that could lead businesses to change the optimal replacement time in response to changes in capital depreciation rules for tax purposes.

\subsection{Composition of the Aggregate Investment}

To interpret the estimated depreciation rates reported above, recall that these estimates are based on the annual net capital stock data which are constructed by the Bureau of Economic Analysis using a straight line depreciation formula, that assumes equal dollar depreciation over the life of the asset. ${ }^{13}$ For this, each type of investment is divided into categories, each category with specific service life. For example, each type of investment in business structure is divided into 23

categories with service lives ranging from 45 percent to 155 percent of the category mean. ${ }^{14}$ This way, each investment category is depreciated following the straight line formula (where annual depreciation for a fixed asset is equal to its gross value divided by its service life) and then the series in each category are aggregated to construct the aggregate figures. ${ }^{15}$

The implication of this procedure is that the changes in the aggregate depreciation rates estimated here must be driven by changes in the composition of the aggregate investment. ${ }^{16}$ To see this, consider first the composition of the gross private nonresidential fixed capital stock. According to Figure 2, the share of producer durable goods in the gross private nonresidential fixed capital stock has increased from about 36 percent to about 48 percent.

Next, I compute the share of all four categories in the total gross capital stock of producer durable goods during the 1948-1989 period. These categories include (1) industrial equipment, (2) industrial machinery and other equipment, (3) transportation and related equipment, and (4) information processing and related equipment. All the original capital stock series used in this paper are computed using constant-cost valuation (in 1987 dollars) and their source is Bureau of Economic Analysis (1993). Figure 3 displays the share of each of the four types of capital stock in the total stock of aggregate producer durable goods. As the figure indicates, the share of the four components has been behaving very differently.

With the exception of approximately two percent decline during the end of 1940s, the share of industrial equipment in total capital stock of producer durable goods has almost steadily increased from 38 percent in 1925 to about 45 percent in early 1960s. However, since 1962, it has 
been continuously declining to about 35 percent in 1989 .

The share of industrial machinery and other equipment fluctuated between 18-20 percent until the beginning of the 2nd World War. Then it increased steadily until late 1940s and early 1950s, reaching the peak of 26 percent. Since then the share of industrial machinery and other equipment in total stock of producer durable goods has been declining with the exception of the 1970-78, where it remained steady around 25 percent. Since 1978 it has been declining monotonically dropping to about 18 percent in 1989.

The share of transportation and related equipment in the total stock of producer durable goods indicates the sharpest decline in comparison to the other two components discussed above. As the figure suggests, the share has been declining almost steadily from about 42 percent in 1925 to 20 percent in 1989. The share was steady around 24 percent in 1960s.

The share of information processing and related equipment stock in producer durable goods has been increasing monotonically since the beginning of the sample period from less than two percent in 1925, to about 25 percent in 1989. Close examination of the plot reveals that this increase in the share of information processing and related equipment stock in producer durable goods has accelerated twice: once in early 1940s in the middle of the 2nd World War, and second time, in the early 1980 s.

In sum, the data displayed in Figures 2 and 3 indicate that the composition of the private nonresidential fixed capital stock and of producer durable good capital stock has changed significantly. According to these data, the increased share of producer durable goods and equipment in the capital stock reflects the growth in the productivity of producer durable goods and equipment relative to business structures. In addition, I find that within the group of producer durable goods, the share of information processing and related equipment has been steadily increasing while the share of industrial and transportation equipment has been decreasing.

In Table 3, I report the average service lives of the capital stock of producer durable goods, nonresidential business structures, and total capital stock. In the table, total capital stock is defined as the sum of producer durable goods and nonresidential business structures. ${ }^{17}$ According to the table, the average service life of capital stock has been continuously declining from about 30 years in 1950, to an average of 25 years in 1985. If we examine each of the two categories in total capital stock, we find that the average service life of producer durable goods and equipment has declined by more than 10 percent. The variation in the average service life of nonresidential 
business structures is not as dramatic, declining by 3.7 percent during the $1950-85$ period.

Information processing and related equipment, which basically covers computers and various types of computerized equipment, is assigned the shortest average service life by the Bureau of Economic Analysis in comparison to other components (or subcomponents) of the stock of producer durable goods. ${ }^{18}$ An increase in the share of shorter-lived assets in the total stock of producer durable goods will therefore yield higher implied annual depreciation rate, which is what we find here. ${ }^{19}$ At the same time, this process should also result in a decrease of the average service life of producer durable goods. Indeed, as Oliner (1989) shows and as Table 3 indicates, the average service life of the gross stock of producer durable goods fell from about 30 years in 1948 to 25 years in 1989. Thus, the increased investment in information processing and computerized equipment, which have shorter lives than traditional industrial equipment, and the increase in the share of producer durable goods in the total stock of nonresidential business fixed capital at the expense of nonresidential business structures, led to the increased implied depreciation rates.

\subsection{Capital Depreciation Rules for Tax Purposes and Optimal Replacement of Capital}

The fixed capital depreciation rules for tax purposes are another key factor determining capital stock depreciation rates. In 1981 Reagan administration introduced the Accelerated Cost Recovery System (henceforth ACRS), which was modified in 1986 Tax Reform Act as the Modified Accelerated Cost Recovery System (henceforth MACRS). These laws were introduced to encourage capital investment by increasing the rate at which most fixed assets could be depreciated and therefore increase the present value of tax shield from depreciation.

Until the introduction of the ACRS, the fundamental principle used in depreciation calculations was that for tax purposes an asset should be depreciated over its useful life. With the introduction of ACRS the notion of "useful life" was dropped altogether, and instead the notion of "recovery period" was introduced. According to this principle, a fixed asset is categorized into a recovery period and is depreciated over this time period regardless of its true "useful life." The system includes four recovery periods: 3 years (for cars, light trucks, and computers), 5 years (for office furniture and fixtures, and manufacturing machinery and equipment), 10 years (for coal burning equipment, mobile homes, and railroad tank cars), and 18 years (for buildings and structures). ${ }^{20}$

This accelerated depreciation mechanism could have an important impact on the effective 
depreciation rate of producer durable goods and equipment as the acceleration of the depreciation rate makes the present value of the tax shield higher. This is especially significant for the last decade, since during the last 10-15 years large part of the purchases in this category consist of computers and computerized equipment which become obsolete in relatively short period of time as new technologies and innovations are introduced in the computer industry at a very rapid rate. The effect of MACRS mechanism on the depreciation rate of the producer durable goods is clearly visible in Figure 1, which indicates a sharp change in the slope right in 1986. The effect of the ACRS seems to coincide with the effect of the second oil price shock. This interpretation of the effect of ACRS and MACRS is consistent with the findings reported by Feldstein and Rothschild (1974) that changes in tax laws governing depreciation accounting (such as accelerated depreciation for tax purposes) may change the optimal durability of equipment, which in turn influences the replacement investment.

\section{Summary and Conclusions}

In this paper I estimate a time varying annual depreciation rate of all three categories of the aggregate capital stock: consumer durable goods, producer durable goods and equipment, and nonresidential business structures, for the post-war U.S. economy. For this I exploit the dynamic relationship between capital stock and the corresponding capital investment series and use annual beginning-of-the-year and end-of-the-year capital stock data to estimate the implied quarterly depreciation rates by numerical iteration over the depreciation rates until a convergence is achieved.

The estimation results suggest that the three depreciation rate series have been behaving very differently over time. In particular, I find that over time the implied depreciation rate of nonresidential business structures has remained stable, the implied depreciation rate of consumer durable goods has been steadily declining, while the implied depreciation rate of producer durable goods has been increasing, especially during the last 10-15 years. These findings are interpreted in terms of the changes in the composition of the aggregate nonresidential business fixed and producer durable good capital stocks. In addition, I discuss the implications of the changes introduced during the 1980s in rules and regulations governing a depreciation accounting for tax purposes, and their effect on the estimates of capital depreciation rates derived in this paper.

The main point this paper makes is that the technological progress of the last 15-20 years, made primarily in the fields of computers and computerized equipment, seems to have caused the implied 
depreciation rate to increase over this time period. This is because the technological advancements have made these equipment obsolete faster than they would be otherwise. The observed changes in the composition of the aggregate investment documented in Section 4.1 is consistent with the accelerated implied depreciation rate of producer durable goods and equipment. In particular, I find that the share of various types of computers and computerized equipment has been steadily increasing at the expense of more traditional equipment. In addition, I find that the share of producer durable goods itself has increased from about 35 percent in the late 1940s to almost 50 percent of the total stock of nonresidential business fixed capital in the late 1980s. Both of these trends lead to an increase in the share of relatively more short-lived components in the aggregate capital stock leading to higher depreciation rates. The fact that during the last decade computers and computerized equipment had become obsolete within 2-4 year period from the date of production because of the fast technological innovations in computer industries, supports this view. This in turn implies that more and more firms are benefiting from faster replacement of older capital equipment since the resulting productivity and efficiency gains apparently outweigh the adjustment cost involved in acquiring and installing new capital equipment. The introduction of ACRS and MACRS laws during the 1980s obviously had additional impact on the implied depreciation rates. The two oil price shocks also seem to have had a noticeable effect on the implied capital stock depreciation rates.

These findings have implications for the behaviour of investment and its components. The finding of accelerated depreciation rate of producer durable goods during the 1970s and 1980s suggest that, ceteris paribus, replacement investment in the 1980s has accelerated as a direct result of the accelerated depreciation. Since net investment depends on depreciation, the accelerated depreciation of producer durable goods reported here may have also played a role in the decline of net investment the U.S. economy has experienced during the 1980s. Indeed, Pieper (1993) considers various factors that may affect net investment, and concludes that the accelerated depreciation of producer durable goods and equipment during the 1980s may account for as much as one-quarter of the decline in net investment during that period. ${ }^{21}$ 


\section{Footnotes}

1. See Holmes (1923).

2. An additional factor affecting the depreciation is capacity utilization which ideally would be treated as endogenous. See, for example, Motahar (1993) and Bils (1994).

3. Using a different line of argument, Feldstein and Rothschild (1974, p. 395) also conclude that “... there is little reason to believe that the economy's capital stock decays at a constant exponential rate." Note that if depreciation is tied to replacement investment as Eisner (1972) suggests, then this argument is even stronger. This is because Eisner (1972) and Feldstein and Rothschild (1974) show that the assumption of constant rate of replacement investment may not be valid. Instead, they argue, replacement investment is an economic decision made by optimizing agents. Therefore, replacement investment will respond to changes in variables such as tax laws, technical progress, factor prices, and interest rate. It follows that in a dynamic setup, replacement investment rate, and consequently depreciation rate, will in general be time varying.

4. It should be mentioned that most countries do not count consumer durable goods as a part of the aggregate capital stock. The U.S. is a rare exception in this regard.

5. Feldstein and Rothschild (1974) distinguish between the various components of depreciation. As Bailey (1962, p. 279) argues, "a true estimate of depreciation would be what it costs at current prices to maintain total wealth intact. In practice, however, what is usually estimated is what it costs to maintain constant the money value of total wealth, using the original cost of the wealth rather than its current replacement cost."

6. Note that once the annual depreciation rates are determined, we can use the equations (1)-(4) to estimate quarterly capital stock series. Using this procedure as well as three other alternative procedures, I have constructed nominal and real quarterly aggregate (gross and net) capital stock series of all three categories in the aggregate capital stock. The constructed quarterly capital stock 
series are reported in Levy and Chen (1994) and they are available upon request from the author.

7. The capital stock series used here differs from the less known capital "input" series constructed by the Bureau of Labor Statistics since 1983. The capital input series, which is especially designed for productivity analysis, is constructed as a weighted aggregate of various types of capital stock and measures the remaining productive services available in the capital stock. Different types of capital provide different level of capital service flow. The weights used in the construction of the capital input series are designed to capture these differences. Since these weights do not reflect utilization rate changes, the capital input series do not provide a good measure of the service flow. The capital stock series used here is constructed by the Bureau of Economic Analysis and is primarily designed to measure national wealth. Consequently, these series reflect the cost of purchasing physical capital. See Oliner (1989), Hulten (1990), and Triplett (1992) for a detailed comparison of these two capital stock series and the methods used in constructing them.

8. The Accelerated Cost Recovery System Tax Act of 1981 and the Modified Accelerated Cost Recovery System Tax Act of 1986 are described and further discussed below.

9. Some authors question the constancy of measured depreciation rates over time when the depreciation rate is estimated using used physical asset prices. They argue that used asset prices respond to changes in variables like taxes, interest rates, and capital asset market conditions. Therefore, a change in the price of an used physical asset does not necessarily indicate an economic depreciation. See, for example, Taubman and Rasche (1971) and Feldstein and Rothschild (1974). Another weakness of this approach is a sample selection problem as discussed by Hulten and Wykoff (1981b).

10. As discussed in section 4 , the acceleration in the depreciation rate during the last $10-15$ years is a result of two main developments. The first development is the change in the composition of the aggregate investment towards higher share of producer durable goods at the expense of nonresidential business structures. This shift has been driven by faster growth in the productivity of producer durable goods relative to business structures. In particular, the advancements in 
computer technology has significantly improved the cost-benefit balance of producer durable goods in comparison to business structures. In addition, there was a shift in the composition of producer durable goods towards towards short-lived assets like computers, computerized equipment, information processing equipment, etc. The second development is the change in tax rules that govern capital depreciation for accounting purposes. These changes took place in 1981 and 1986, after the years covered in Shriver's (1986) study. See further discussion below.

11. Since they only report averages for some subperiods, a comparison of their estimates with mine year by year basis is not possible.

12. See Musgrave (1992) for a detailed description of these revisions of the national income and product account data.

13. Hudson and Mathews (1963) show that the straight line depreciation formula is theoretically valid only when the expected net services delivered by an asset decline at a particular rate. To see this, suppose that the price of the product produced by capital is expected to remain constant during its lifetime. Then, since the annual return ("profit component") on the capital must decline from year to year, the depreciation component will increase unless the net return ("net services") declines at just the rate which will keep the depreciation component constant [Harcourt (1972)]. For justification of the straight-line formula see the discussion in Young and Musgrave (1980). More accelerated depreciation mechanisms and formulas are discussed by Terborgh (1954) and Jorgenson (1989).

14. The service lives are computed using Winfrey's (1967) retirement curve by taking into account the fact that different assets are retired at different age.

15. See Bureau of Economic Analysis (1993) for further details.

16. This is the reason for using the term "implied depreciation rate" throughout this paper.

17. The source of these figures is Oliner (1989). Average service lives of consumer durable 
goods are not shown.

18. This is compatible with the estimated depreciation rate of office and computing machinery reported by Hulten and Wykoff (1981). According to their finding, that rate is 0.273 . They report depreciation rate of many fixed asset categories, and the depreciation rate of office and computing machinery is the second highest, the first being automobiles. Since the publication of their study the pace of technological innovation in the field of office and computing machinery has significantly increased making computer equipment purchased as recently as couple of years ago, obsolete. Therefore, it is safe to conjecture that the depreciation rate of computer equipment during the last decade is even higher than Hulten and Wykoff's (1981) estimate.

19. Note that within the category of information processing and related equipment, the average service life of office, computing, and accounting machinery is 7 years. See Bureau of Economic Analysis (1993, Table B, p. M-17) for a detailed listing of the average service lives by type of asset used by the U.S. Department of Commerce to derive its annual capital stock estimates.

20. The ACRS accelerated depreciation rates for these recovery periods are as follows. For the 3 -year recovery period the depreciation rates for the first, second, and third year are $25 \%, 38 \%$, $37 \%(\Sigma=100 \%)$, respectively. Similarly, for the 5-year recovery period the depreciation rates are $15 \%, 22 \%, 21 \%, 21 \%, 21 \%(\Sigma=100 \%)$. For the 10-year recovery period the depreciation rates are $8 \%, 14 \%, 12 \%, 10 \%, 10 \%, 10 \%, 9 \%, 9 \%, 9 \%, 9 \%(\Sigma=100 \%)$. Finally for the $18-$ year recovery period the depreciation rates are $4 \%, 8 \%, 7 \%, 7 \%, 6 \%, 6 \%, 6 \%, 6 \%, 5 \%, 5 \%$, $5 \%, 5 \%, 5 \%, 5 \%, 5 \%, 5 \%, 5 \%, 5 \%(\Sigma=100 \%)$. Notice that the depreciation rate for the first year of each period is lower than for the second year. This was one of the modifications introduced in 1986: since a firm will own the asset only for part of the first year (unless it was purchased on January 1), the MACRS introduced the "half-year" convention which treats all fixed capital assets as if they were purchased in the middle of the year.

21. Other factors Pieper (1993) considers include output growth and capital-output ratio. 


\section{References}

Bailey, Martin J. (1962). National Income and the Price Level. New York, NY: McGraw-Hill.

Bils, Mark and Jang-Ok Cho (1994). Cyclical factor utilization. Journal of Monetary Economics, 33, 319-354.

Bureau of Economic Analysis (1993). Fixed Reproducible Tangible Wealth in the United States, 1925-89. Washington, DC: U.S. Department of Commerce, January.

Citicorp Database Services (1992). CITIBASE: Macroeconomic Database.

Eisner, Robert (1972). Components of capital expenditures: replacement and modernization versus expansion. Review of Economics and Statistics, 54, August, 297-306.

Feldstein, Martin S. and David K. Foot (1971). The other half of gross investment: replacement and modernization investment. Review of Economics and Statistics, 53, February, 49-58.

Feldstein, Martin S. and Michael Rothschild (1974). Towards an economic theory of replacement investment. Econometrica, 42, May, 393-423.

Gordon, Robert J. and John M. Veitch (1986). Fixed investment in the american business cycle: 1919-83. In Robert J. Gordon (ed.), The American Business Cycle: Continuity and Change. Chicago, IL: The University of Chicago Press, 267-335.

Harcourt (1972). Some Cambridge Controversies in the Theory of Capital. Cambridge: Cambridge University Press.

Holmes, Oliver Wendell (1923). The deacon's masterpiece or, the wonderful 'One-Hoss Shay': a logical story. In The Complete Poetical Works of Oliver Wendell Holmes. Boston: Houghton Mifflin, Cambridge Edition, 158-160.

Hudson, H.R. and R.L. Mathews (1963). An aspect of depreciation. Economic Record, 39, $232-36$.

Hulten, Charles R. (1990). The measurement of capital. In Fifty Years of Economic Measurement, edited by Ernst R. Berndt and Jack E. Triplett. Chicago: National Bureau of Economic Research.

Hulten, Charles R. and Frank C. Wykoff (1981a). The estimation of economic depreciation using vintage asset prices. Journal of Econometrics, 15, 367-96.

Hulten, Charles R. and Frank C. Wykoff (1981b). The measurement of economic depreciation," in Depreciation, Inflation, and the Taxation of Income from Capital, edited by Charles R. Hulten. Washington: Urban Institute Press, 81-125.

Jorgenson, Dale W. (1989). Capital as a factor of production. In Technology and Capital 
Formation, edited by Dale W. Jorgenson and Ralph Landau. Cambridge, MA: The MIT Press.

Levy, Daniel and Haiwei Chen (1994). Estimates of quarterly aggregate capital stock series for the post-war U.S. economy. The Review of Income and Wealth, Series 40, No. 3, September, 317-349.

Motahar, Eshi (1993). Endogenous capital utilization and the $q$ theory of investment. Economics Letters, 40, 71-76.

Musgrave, John C. (1992). Fixed reproducible tangible wealth in the United States, revised estimates. Survey of Current Business, January, 106-135.

Oliner, Stephen D. (1989). The formation of private business capital: trends, recent developments, and measurement issues. Federal Reserve Bulletin, 75, No. 12, December, 771-783.

Pieper, Paul (1993). Why has net investment fallen?. unpublished working paper.

Robinson, Joan (1953). The production function and the theory of capital. Review of Economic Studies, 21, 81-106.

Shriver, Keith A. (1986). A statistical test of the stability assumption inherent in empirical estimates of economic depreciation. Journal of Economic and Social Measurement, 14, 145-153.

Taubman, Paul and Robert Rasche (1971). Subsidies, economic lives, and complete resource misallocation. American Economic Review, 61, 938-945.

Terborgh, George (1954). Realistic Depreciation Policy. Washington, DC: Machinery and Allied Products Institute.

Triplett, Jack (1992). Measuring the capital stock: a review of concepts and data needs. Presented at the Workshop on the Measurement of Depreciation and Capital Stock, Conference on Research in Income and Wealth, National Bureau of Economic Research, Washington, DC, June 5, 1992.

Wicksell, Knut J.G. (1934). Lectures on Political Economy, Volume 1, translated from 3rd edition by E. Classen. New York: Routledge \& Kegan Paul.

Winfrey, Robley (1967). Statistical Analysis of Industrial Property Retirements, Bulletin 125 Revised. Ames, IA: Engineering Research Institute, Iowa State University, April.

Young, Allan H. and John C. Musgrave (1980). Estimation of Capital Stock in the US. In The Measurement of Capital, edited by Dan Usher. Chicago: National Bureau of Economic Research. 
Table 1

Exponentially Compounded Annual Capital Stock Depreciation Rates, U.S., 1948-91

\begin{tabular}{|c|c|c|c|}
\hline Years & $\begin{array}{l}\text { Consumer Durable } \\
\text { Goods }\end{array}$ & $\begin{array}{c}\text { Producer Durable } \\
\text { Goods }\end{array}$ & $\begin{array}{l}\text { Nonresidential Business } \\
\text { Structures }\end{array}$ \\
\hline 1948 & 0.2725 & 0.1168 & 0.0589 \\
\hline 1949 & 0.2716 & 0.1151 & 0.0576 \\
\hline 1950 & 0.2687 & 0.1168 & 0.0555 \\
\hline 1951 & 0.2449 & 0.1172 & 0.0601 \\
\hline 1952 & 0.2482 & 0.1168 & 0.0509 \\
\hline 1953 & 0.2482 & 0.1198 & 0.0539 \\
\hline 1954 & 0.2587 & 0.1225 & 0.0530 \\
\hline 1955 & 0.2672 & 0.1251 & 0.0534 \\
\hline 1956 & 0.2606 & 0.1238 & 0.0509 \\
\hline 1957 & 0.2596 & 0.1246 & 0.0509 \\
\hline 1958 & 0.2615 & 0.1268 & 0.0514 \\
\hline 1959 & 0.2711 & 0.1268 & 0.0493 \\
\hline 1960 & 0.2668 & 0.1259 & 0.0493 \\
\hline 1961 & 0.2610 & 0.1259 & 0.0485 \\
\hline 1962 & 0.2630 & 0.1251 & 0.0480 \\
\hline 1963 & 0.2625 & 0.1251 & 0.0480 \\
\hline 1964 & 0.2601 & 0.1238 & 0.0476 \\
\hline 1965 & 0.2544 & 0.1229 & 0.0480 \\
\hline 1966 & 0.2449 & 0.1238 & 0.0497 \\
\hline 1967 & 0.2393 & 0.1220 & 0.0493 \\
\hline 1968 & 0.2374 & 0.1207 & 0.0485 \\
\hline 1969 & 0.2365 & 0.1185 & 0.0480 \\
\hline 1970 & 0.2341 & 0.1194 & 0.0485 \\
\hline 1971 & 0.2374 & 0.1194 & 0.0485 \\
\hline 1972 & 0.2407 & 0.1233 & 0.0514 \\
\hline 1973 & 0.2360 & 0.1225 & 0.0509 \\
\hline 1974 & 0.2290 & 0.1198 & 0.0514 \\
\hline 1975 & 0.2281 & 0.1229 & 0.0497 \\
\hline 1976 & 0.2318 & 0.1259 & 0.0522 \\
\hline
\end{tabular}


Table 1. Cont.

\begin{tabular}{cccc}
\hline Years & $\begin{array}{c}\text { Consumer Durable } \\
\text { Goods }\end{array}$ & $\begin{array}{c}\text { Producer Durable } \\
\text { Goods }\end{array}$ & $\begin{array}{c}\text { Nonresidential Business } \\
\text { Structures }\end{array}$ \\
\hline 1977 & 0.2318 & 0.1268 & 0.0526 \\
1978 & 0.2257 & 0.1290 & 0.0522 \\
1979 & 0.2201 & 0.1290 & 0.0534 \\
1980 & 0.2188 & 0.1281 & 0.0522 \\
1981 & 0.2178 & 0.1321 & 0.0530 \\
1982 & 0.2192 & 0.1382 & 0.0543 \\
1983 & 0.2215 & 0.1400 & 0.0539 \\
1984 & 0.2188 & 0.1440 & 0.0530 \\
1985 & 0.2178 & 0.1435 & 0.0509 \\
1986 & 0.2164 & 0.1435 & 0.0522 \\
1987 & 0.2123 & 0.1466 & 0.0526 \\
1988 & 0.2113 & 0.1537 & 0.0530 \\
1989 & 0.2113 & 0.1493 & 0.0530 \\
1990 & 0.2146 & 0.1542 & 0.0518 \\
1991 & 0.2192 & 0.1569 & 0.0526 \\
\hline
\end{tabular}

Source: Author's computations. 
Table 2

Exponentially Compounded Average Annual Capital Stock Depreciation Rates, U.S., 1948-91

\begin{tabular}{lccc}
\hline Period & $\begin{array}{c}\text { Consumer Durable } \\
\text { Goods }\end{array}$ & $\begin{array}{c}\text { Producer Durable } \\
\text { Goods }\end{array}$ & $\begin{array}{c}\text { Nonresidential Business } \\
\text { Structures }\end{array}$ \\
\hline $1948-1991$ & 0.2403 & 0.1285 & 0.0517 \\
$1948-1972$ & 0.2548 & 0.1219 & 0.0511 \\
$1973-1991$ & 0.2211 & 0.1372 & 0.0524 \\
$1981-1991$ & 0.2164 & 0.1456 & 0.0527 \\
$1986-1991$ & 0.2142 & 0.1507 & 0.0525 \\
\hline
\end{tabular}

Source: Table 1 and Author's computations. 
Table 3

Average Service Lives of the Aggregate Capital Stock, U.S., 1950-85

\begin{tabular}{cccc}
\hline Period & $\begin{array}{c}\text { Total Capital } \\
\text { Stock }\end{array}$ & $\begin{array}{c}\text { Producer Durable } \\
\text { Goods }\end{array}$ & $\begin{array}{c}\text { Nonresidential Business } \\
\text { Structures }\end{array}$ \\
\hline 1950 & 29.56 & 98.00 & 99.92 \\
1955 & 28.32 & 96.06 & 98.45 \\
1960 & 27.96 & 96.15 & 97.60 \\
1965 & 27.84 & 96.40 & 97.50 \\
1970 & 27.30 & 95.03 & 98.80 \\
1975 & 26.67 & 93.20 & 98.40 \\
1980 & 25.79 & 91.00 & 97.60 \\
1985 & 25.10 & 88.10 & 96.20 \\
\hline
\end{tabular}

Notes on Table 3:

1. Average service lives of total capital stock are measured in years. Total capital stock here is defined as the sum of producer durable goods and nonresidential business structures.

2. The figures for producer durable goods and nonresidential business structures are index numbers with $1948=100$.

3. The figures in the first column are the weighted average of the Bureau of Economic Analysis' estimate of service life for each type of producer durable good and nonresidential business structure. The weight of each type equals its share in the gross private nonresidential fixed capital stock.

4. The figures in the second column are the weighted average of the Bureau of Economic Analysis' estimate of service life for each type of producer durable good. The weight of each type equals its share in the total stock of gross producer durable goods. The figures in the third column are the weighted average of the Bureau of Economic Analysis' estimate of service life for each type of nonresidential business structure. The weight of each type equals its share in the total stock of nonresidential business structures.

5. Source: Oliner (1989), Chart 4. 


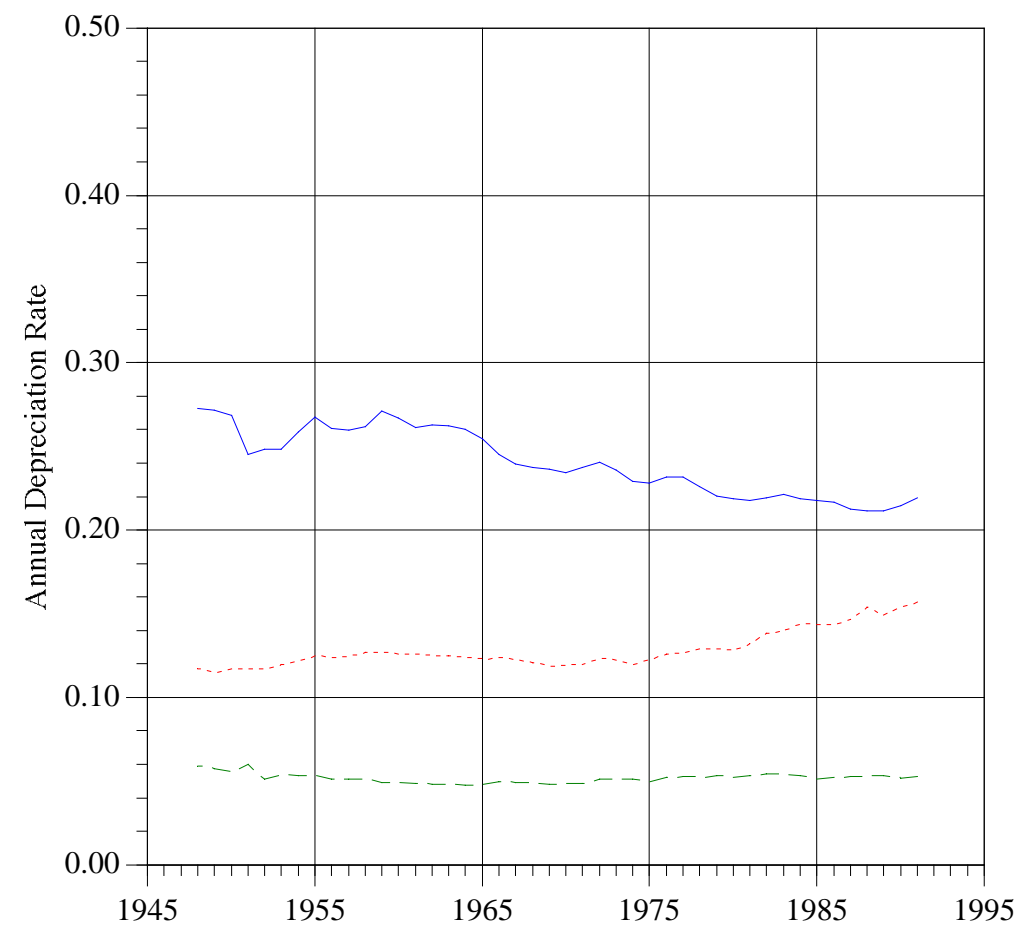

Consumer Durable Goods

Producer Durable Goods and Equipment

Nonresidential Business Structures

Figure 1. Exponentially compounded time varying depreciation rates of the aggregate capital stock: consumer durable goods, producer durable goods and equipment, and nonresidential business structures, U.S., 1948-91. 


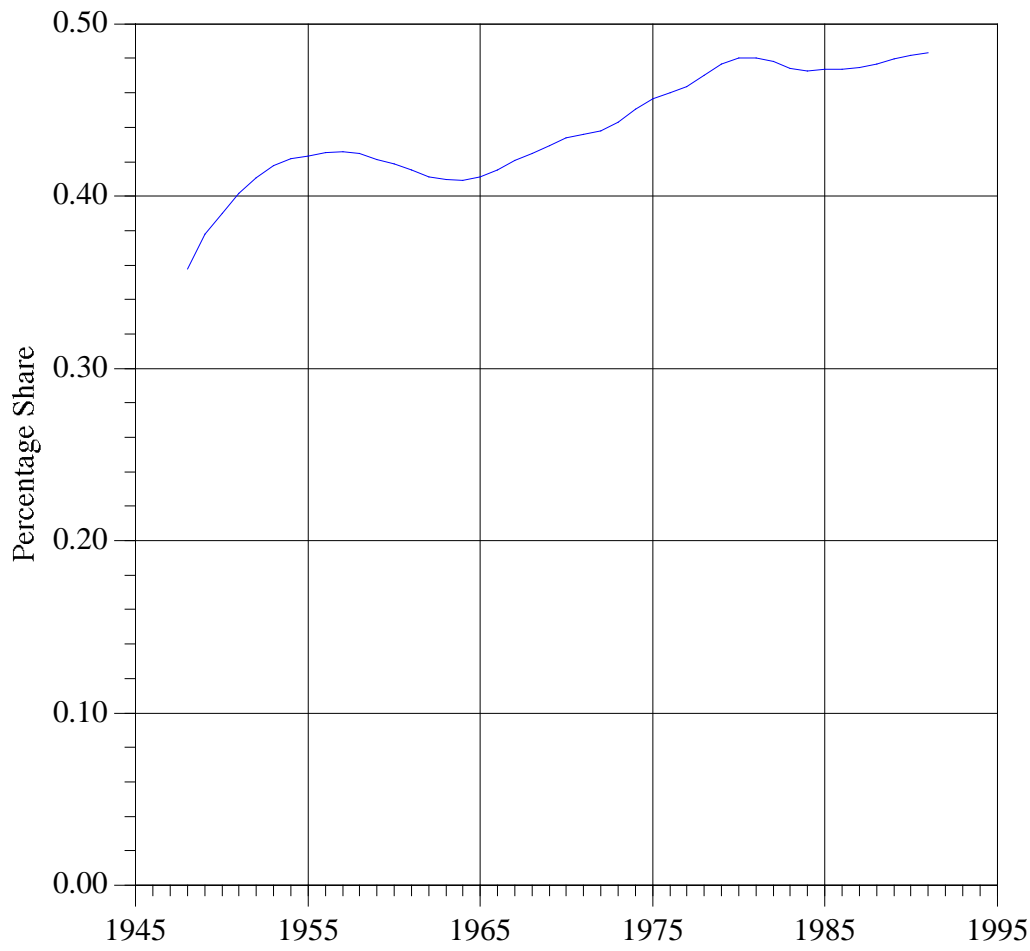

Figure 2. The share of producer durable goods in the gross private nonresidential fixed capital stock, constant-cost valuation, 1987 \$s, U.S., 1948-89. 


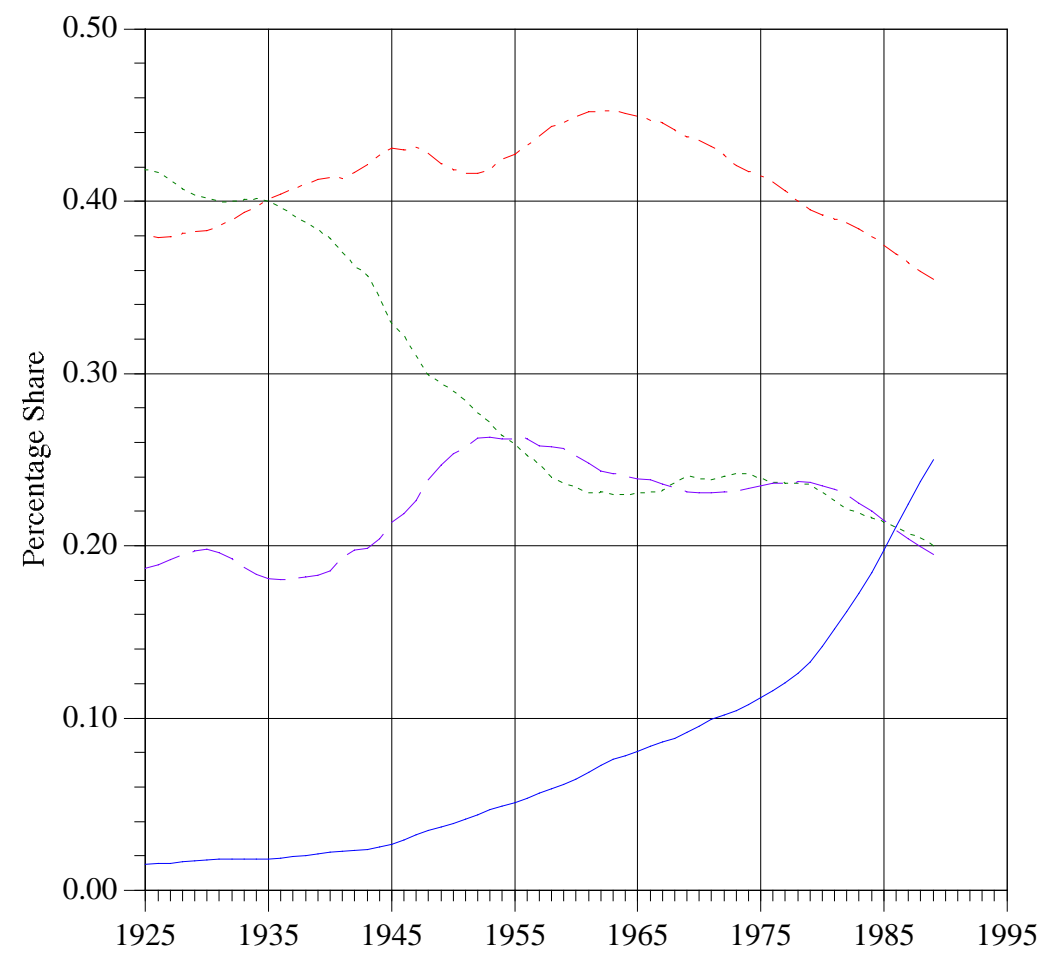

Figure 3. The share of information processing and related equipment, industrial equipment, transportation and related equipment, and industrial machinery and other equipment in total gross capital stock of producer durable goods, constant-cost valuation, 1987 \$s, U.S., 1925-89. 